\title{
Article \\ Hypoglycemia, Vascular Disease and Cognitive Dysfunction in Diabetes: Insights from Text Mining-Based Reconstruction and Bioinformatics Analysis of the Gene Networks
}

\author{
Olga V. Saik ${ }^{1,2}$ and Vadim V. Klimontov ${ }^{1, *(1)}$ \\ 1 Laboratory of Endocrinology, Research Institute of Clinical and Experimental Lymphology—Branch of the \\ Institute of Cytology and Genetics, Siberian Branch of Russian Academy of Sciences (RICEL-Branch of ICG \\ SB RAS), 630060 Novosibirsk, Russia; saik@bionet.nsc.ru \\ 2 Laboratory of Computer Proteomics, Federal Research Center Institute of Cytology and Genetics, Siberian \\ Branch of the Russian Academy of Sciences (ICG SB RAS), 630090 Novosibirsk, Russia \\ * Correspondence: klimontov@mail.ru
}

Citation: Saik, O.V.; Klimontov, V.V. Hypoglycemia, Vascular Disease and Cognitive Dysfunction in Diabetes: Insights from Text Mining-Based Reconstruction and Bioinformatics Analysis of the Gene Networks. Int. J. Mol. Sci. 2021, 22, 12419. https:// doi.org/10.3390/ijms222212419

Academic Editor: Ramzi Ajjan

Received: 20 October 2021

Accepted: 16 November 2021

Published: 17 November 2021

Publisher's Note: MDPI stays neutral with regard to jurisdictional claims in published maps and institutional affiliations.

Copyright: (c) 2021 by the authors. Licensee MDPI, Basel, Switzerland. This article is an open access article distributed under the terms and conditions of the Creative Commons Attribution (CC BY) license (https:/ / creativecommons.org/licenses/by/ $4.0 /)$.

\begin{abstract}
Hypoglycemia has been recognized as a risk factor for diabetic vascular complications and cognitive decline, but the molecular mechanisms of the effect of hypoglycemia on target organs are not fully understood. In this work, gene networks of hypoglycemia and cardiovascular disease, diabetic retinopathy, diabetic nephropathy, diabetic neuropathy, cognitive decline, and Alzheimer's disease were reconstructed using ANDSystem, a text-mining-based tool. The gene network of hypoglycemia included 141 genes and 2467 interactions. Enrichment analysis of Gene Ontology (GO) biological processes showed that the regulation of insulin secretion, glucose homeostasis, apoptosis, nitric oxide biosynthesis, and cell signaling are significantly enriched for hypoglycemia. Among the network hubs, INS, IL6, LEP, TNF, IL1B, EGFR, and FOS had the highest betweenness centrality, while GPR142, MBOAT4, SLC5A4, IGFBP6, PPY, G6PC1, SLC2A2, GYS2, GCGR, and AQP7 demonstrated the highest cross-talk specificity. Hypoglycemia-related genes were overrepresented in the gene networks of diabetic complications and comorbidity; moreover, 14 genes were mutual for all studied disorders. Eleven GO biological processes (glucose homeostasis, nitric oxide biosynthesis, smooth muscle cell proliferation, ERK1 and ERK2 cascade, etc.) were overrepresented in all reconstructed networks. The obtained results expand our understanding of the molecular mechanisms underlying the deteriorating effects of hypoglycemia in diabetes-associated vascular disease and cognitive dysfunction.
\end{abstract}

Keywords: hypoglycemia; diabetes; cardiovascular disease; diabetic retinopathy; diabetic nephropathy; cognitive dysfunction; Alzheimer's disease; diabetic neuropathy; gene networks; ANDsystem

\section{Introduction}

Hypoglycemia is a life-threatening complication and a barrier to achieving good glycemic control in patients with diabetes [1]. The long-term consequences of hypoglycemia include cardiovascular events, as well as cognitive and psychological problems [2]. In both type 1 and type 2 diabetes, self-reported episodes of severe hypoglycemia are related to increased risk of death [3]. Large prospective clinical studies have documented the association between severe diabetes-related hypoglycemia and major adverse cardiovascular events: cardiovascular and all-cause mortality [4-6]. In diabetes, the link between severe hypoglycemia and cardiovascular events is time-dependent and bidirectional: this means increased cardiovascular risk after severe hypoglycemia, as well as greater risk of severe hypoglycemia after a cardiovascular event [7]. Recent studies indicate a promoting role of hypoglycemia in the progression of microvascular diabetic complications, including retinopathy [8,9] and chronic kidney disease [10]. Decreased kidney function, in turn, increase the risk of hypoglycemia [11]. 
In individuals with diabetes, severe hypoglycemia is an established risk factor for cognitive decline and dementia [12-14]. Recurrent symptomatic or asymptomatic hypoglycemia has been suggested to induce sub-clinical brain damage and permanent cognitive dysfunction [15]. Recent clinical observations suggest that hypoglycemia is a risk factor for both vascular dementia and dementia due to Alzheimer's disease (AD) in elderly patients with type 2 diabetes [16]. These data are consistent with the results of experimental studies indicating that glucose deprivation triggers tau pathology and synaptic dysfunction in the brain, the hallmarks of AD [17,18]. It should be noted that type 2 diabetes can also increase the risk of $\mathrm{AD}$ [14].

It is well known that a glucose-deprived condition triggers a cascade of adaptive and pathophysiological events in the cardiovascular and nervous systems. Cardiovascular effects of hypoglycemia include increase in cardiac work load and potential attenuation of myocardial perfusion, potentially arrhythmogenic electrophysiological changes, induction of a prothrombotic state, and release of inflammatory mediators [19]. An episode of hypoglycemia induces an adaptive counter-regulatory response, which involves enhanced glucagon, epinephrine, cortisol and growth hormone secretion; the suppression of insulin release; and the modulation of the autonomic nervous system. Recurrent or chronic hypoglycemia induces multiple shifts in the brain's metabolism, including glycogen mobilization; the utilization of alternate sources of energy, such as lactate and ketones; changes in glucose uptake; and changes in cellular respiration [20]. However, the molecular mechanisms of the effects of hypoglycemia in the target organs are not fully understood.

Artificial intelligence and bioinformatics open up new possibilities for systems analysis of molecular events in human diseases. Text-mining is a field in artificial intelligence that aims to extract information from collections of text documents based on machine learning and natural language processing techniques. Text-mining is considered a useful tool for integrative biomedical research involving genes, proteins and phenotypes [21]. In this study we applied ANDSystem (ICG SB RAS, Novosibirsk, Russia), a bioinformatics tool that builds molecular (gene) networks by text-mining of PubMed/Medline indexed publications [22-24], for reconstruction and analysis of gene networks of hypoglycemia and diabetes-related conditions for which hypoglycemia may be a risk factor.

The main goal of the ANDSystem is to allow the generation of new hypotheses related to understanding of the molecular mechanisms of complex biological processes by reconstruction and analysis of associative molecular (gene) networks where biological objects are presented as nodes, and interactions between them are presented as edges. For that purpose, a high-throughput technology of automatic knowledge extraction from texts of scientific publications is utilized. For the first step, the text-mining approach performs automated recognition of the names of biological entities in texts. For the second step, it reveals interactions between biological objects using more than 3000 specific semantic templates. The information extracted by the text-mining is stored in the huge ANDCell knowledge base which is updated annually. Information from the ANDCell knowledge base could be queried by users through the ANDVisio client module. The ANDVisio supports network visualization and analysis. For example, ANDVisio functions allow to calculate the connectivity and the centrality coefficients of nodes [22-24]. Previously, the ANDSystem was applied successfully to analyze the molecular basis of a number of human diseases and comorbidity [25-28].

One of the well-established ways to find relations between gene sets obtained in the research and the studied conditions (biological processes, diseases, phenotypes, etc.) is the gene set enrichment analysis. As a result of applying this method, it is possible to identify sets of genes for which the frequency of occurrence in the analyzed set, associated with the target condition, is significantly different from the background frequency (for example, the frequency in the entire genome). Such sets of genes are called overrepresented (if the frequency is higher than the background) or underrepresented (if the frequency is below the background). The hypergeometric distribution is commonly used as a statistical model to assess the significance of enrichment. The examples of web tools that perform the 
gene set enrichment analysis are DAVID [29] and TopAnat function of Bgee [30]. DAVID is aimed to perform comprehensive functional annotation for revealing the biological meaning of a large list of tested genes. It is in particular able to identify enriched Gene Ontology terms [29]. Bgee is a database containing information on gene expression patterns in different tissues and cells. Its TopAnat function allows to find enrichment of anatomical terms related to genes by expression patterns [30]. The gene set enrichment analysis was performed in this work to reveal interconnections between studied genes and hypoglycemia, vascular disease and cognitive dysfunction in diabetes.

Despite the obvious clinical importance of the issue, a gene network of hypoglycemia has not yet been analyzed. The comparative analysis of a network of hypoglycemia and diabetes-related diseases has not been performed also. Therefore, in this study, we reconstructed and matched the gene networks of hypoglycemia, cardiovascular disease, microvascular diabetes complications, cognitive dysfunction and AD with the use of ANDSystem to identify the principal molecules and processes that can mediate the effects of hypoglycemia on the target organs in diabetes.

\section{Results and Discussion}

\subsection{Gene Network of Hypoglycemia}

In our previous work [28], we have reconstructed a gene network associated with hypoglycemia in individuals with diabetes. This network included 128 genes/proteins and 2467 interactions. As the ANDSystem (ICG SB RAS, Novosibirsk, Russia) [22-24] was updated in 2021, the gene network related to hypoglycemia (Figure 1) has been expanded to include 141 genes/proteins and 5525 interactions (Table S1).

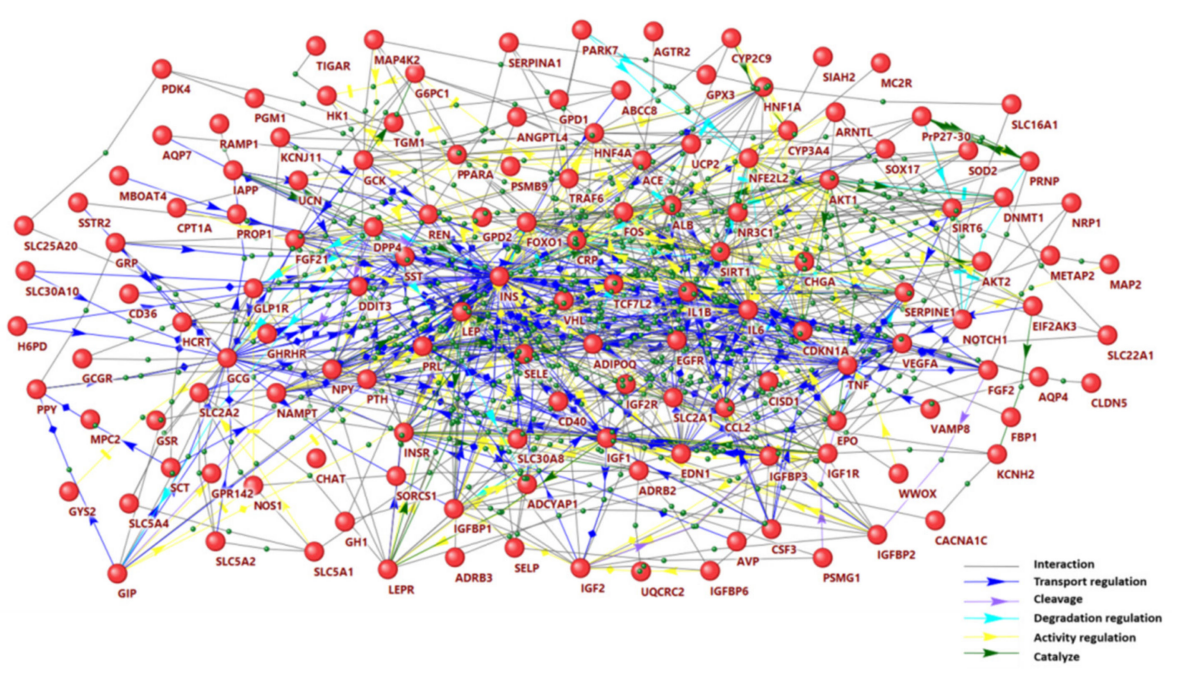

Figure 1. Molecular network of hypoglycemia visualized with the ANDSystem.

The network of hypoglycemia consisted of molecules with different structures and functions. It included insulin and other hormones, cytokines and growth factors, enzymes, transporters, transcription factors, neuropeptides, structural and binding proteins, and microRNAs (Table 1). 
Table 1. Molecules of the hypoglycemia network.

\begin{tabular}{|c|c|}
\hline Group of Molecules & Genes \\
\hline Hormones & $\begin{array}{c}A D I P O Q, A V P, E P O, G C G, G H 1, \text { GIP, IAPP, INS, LEP, PRL, } \\
P T H, R E N, \text { SCT, and SST }\end{array}$ \\
\hline Cytokines and growth factors & $\begin{array}{c}\text { ANGPTL4, CCL2, CSF3, EDN1, FGF2, FGF21, IGF1, IGF2, IL1B, } \\
\text { IL6, TNF, and VEGFA }\end{array}$ \\
\hline Receptors & $\begin{array}{c}\text { ADRB2, ADRB3, AGTR2, CD36, CD40, EGFR, GCGR, GHRHR, } \\
\text { GLP1R, GPR142, IGF1R, IGF2R, INSR, LEPR, MC2R, NOTCH1, } \\
\text { NR3C1, SORCS1, and SSTR2 }\end{array}$ \\
\hline Enzymes & $\begin{array}{l}\text { ACE, AKT1, AKT2, CHAT, CPT1A, CYP2C9, CYP3A4, DNMT1, } \\
\text { DPP4, EIF2AK3, FBP1, G6PC1, GCK, GPD1, GPD2, GPX3, GSR, } \\
\text { GYS2, H6PD, HK1, MAP4K2, MBOAT4, METAP2, NAMPT, } \\
\text { NOS1, PARK7, PDK4, PGM1, SERPINA1, SIAH2, SIRT1, SIRT6, } \\
\text { SOD2, TGM1, TIGAR, UQCRC2, VHL, and WWOX }\end{array}$ \\
\hline Transporters & $\begin{array}{l}A B C C 8, A Q P 4, A Q P 7, C A C N A 1 C, K C N J 11, K C N H 2, M P C 2, \\
\text { RAMP1, SLC5A1, SLC5A2, SLC5A4, SLC16A1, SLC2A1, } \\
\text { SLC2A2, SLC22A1, SLC30A8, SLC25A20, SLC30A10, and UCP2 }\end{array}$ \\
\hline Transcription factors & $\begin{array}{c}\text { ARNTL, DDIT3, FOS, FOXO1, HNF1A, HNF4A, NFE2L2, } \\
\text { NR3C1, PPARA, PROP1, SOX17, and TCF7L2 }\end{array}$ \\
\hline Neuropeptides & ADCYAP1, CHGA, GRP, HCRT, NPY, PPY, and UCN \\
\hline Structural proteins & CLDN5 and MAP2 \\
\hline Other proteins & $\begin{array}{c}\text { ALB, CDKN1A, CISD1, CRP, IGFBP1, IGFBP2, IGFBP3, } \\
\text { IGFBP6, NRP1, PRNP, PSMB9, PSMG1, SELE, SELP, } \\
\text { SERPINE1, TRAF6, and VAMP8 }\end{array}$ \\
\hline MicroRNAs & MIR155 and MIR410 \\
\hline
\end{tabular}

Expectedly, genes encoding hormones that regulate glucose metabolism including insulin (INS), glucagon (GCG), glucagon-like peptide 1 (GCG), glucose-dependent insulinotropic polypeptide (GIP), islet amyloid polypeptide (IAPP), growth hormone (GH1), and some hormonal receptors (INSR, GLP1R, ADRB2, ADRB3) turned out to be the central hubs of this network. Among identified hormones, insulin plays a key role as an inducer of hypoglycemia, glucagon and growth hormone are involved in the response to hypoglycemia, and other hormones act as modulators of insulin secretion or sensitivity. Alternatively, hypoglycemia itself may affect the secretion of a number of these regulators [31,32]. Some of the identified transcription factors (HNF1A, HNF4A, and TCF7L2) are essential for glucose homeostasis. A group of neuropeptides included modulators of the neuroendocrine system, such as adenylate cyclase-activating polypeptide 1(ADCYAP1), neuromedin $C(G R P)$, and chromogranin $\mathrm{A}(C H G A)$, and some regulators of appetite and food intake, namely, hypocretin neuropeptide precursor (HCRT), neuropeptide Y (NPY), pancreatic polypeptide $Y(P P Y)$, and urocortin $(U C N)$ participated in the network.

Two microRNAs genes (MIR155 and MIR410) identified in the networks were both involved in glucose metabolism. Specifically, in mice, global overexpression of miR155 resulted in hypoglycemia, improved glucose tolerance and enhanced insulin sensitivity of peripheral tissues [33]. MiR-410 enhanced glucose-stimulated insulin secretion in vitro [34]. It is also involved in the brain response to oxygen-glucose deprivation [35].

The nature of the links in the network is shown in Table 2. It was found that 43 genes were up-regulated and 17 genes were down-regulated by hypoglycemia. In turn, the products of 16 genes were able to induce hypoglycemia, and 22 genes were described to have a protective effect against hypoglycemia or involved in the counterregulatory response. The SNPs associated with hypoglycemia were observed in 34 genes. 
Table 2. The patterns of the links between identified genes and hypoglycemia.

\begin{tabular}{|c|c|}
\hline Link & Genes \\
\hline $\begin{array}{c}\text { Gene expression is up-regulated } \\
\text { by hypoglycemia }\end{array}$ & $\begin{array}{c}\text { ADIPOQ, ALB, ANGPTL4, AQP4, AVP, CCL2, CD40, CDKN1A, } \\
\text { CHAT, CHGA, CRP, CYP3A4, DDIT3, EDN1, EIF2AK3, EPO, } \\
\text { FOS, GIP, GH1, GPD1, GPX3, GRP, HCRT, IGFBP1, IGFBP2, } \\
\text { IL6, LEPR, NOS1, NPY, PARK7, PDK4, PPY, PRL, PRNP, REN, } \\
\text { SELE, SERPINE1, SLC2A1, SOD2, SOX17, TIGAR, VEGFA, } \\
\text { and UCN }\end{array}$ \\
\hline $\begin{array}{l}\text { Gene expression is } \\
\text { down-regulated by } \\
\text { hypoglycemia }\end{array}$ & $\begin{array}{c}\text { CLDN5, CPT1A, DNMT1, FBP1, GPD2, GSR, MAP2, METAP2, } \\
\text { NFE2L2, NRP1, PTH, RAMP1, SELP, SLC25A20, SLC2A1, SST, } \\
\text { and VEGFA }\end{array}$ \\
\hline $\begin{array}{l}\text { Molecules with hypoglycemic } \\
\text { or antihyperglycemic activity }\end{array}$ & $\begin{array}{c}\text { CSF3, GIP, GLP1R, IGF1, IGF2, IGF2R, IGFBP6, IL1B, INS, } \\
\text { KCNH2, MIR155, NOTCH1, SCT, SLC16A1, SSTR2, and TRAF6 }\end{array}$ \\
\hline Protective effect against & ADRB3, CD36, FOXO1, GCG, GCGR, DPP4, GH1, IAPP, \\
\hline $\begin{array}{l}\text { hypoglycemia and/or response } \\
\text { to hypoglycemia }\end{array}$ & $\begin{array}{c}\text { IGFBP3, KCNH2, LEP, MBOAT4, MIR410, MPC2, PPARA, PRL, } \\
\text { SLC2A2, SOD2, TNF, VHL, VAMP8, and UCN } \\
A B C C 8, A C E, A D R B 2, A G T R 2, A K T 2, A Q P 7, C A C N A 1 C,\end{array}$ \\
\hline $\begin{array}{l}\text { SNPs associated with the risk of } \\
\text { hypoglycemia }\end{array}$ & $\begin{array}{c}\text { CYP2C9, G6PC, GCK, GHRHR, GYS2, HK1, HNF1A, HNF4A, } \\
\text { IGF1R, INSR, KCNJ11, MAP4K2, MC2R, NR3C1, PGM1, } \\
\text { PROP1, PSMB9, SERPINA1, SIRT6, SLC22A1, SLC2A2, } \\
\text { SORCS1, TCF7L2, TGM1, UCP2, UQCRC2, and WWOX }\end{array}$ \\
\hline Other links & $\begin{array}{l}\text { ADCYAP1, AKT1, ARNTL, CISD1, EGFR, FGF2, FGF21, } \\
\text { GPR142, H6PD, NAMPT, PSMG1, SIAH2, SIRT1, SLC2A2, } \\
\text { SLC30A10, SLC30A8, SLC5A1, SLC5A2, and SLC5A4 }\end{array}$ \\
\hline
\end{tabular}

The distribution of the number of gene connections in the network turned out to be exponential (Figure 2, Table S2). Only seven genes (INS, IL6, LEP, TNF, IL1B, EGFR, and FOS) showed over 100 connections with other elements of the network. All these junction genes were present among the top 15 genes with the highest betweenness centrality (Figure 2, Table S3), which suggests their key role in the hypoglycemia pathophysiology. The proteins encoded by these genes regulate glucose and lipid metabolism (INS, LEP), cell proliferation, differentiation and survival (INS, LEP, EGFR, FOS), inflammatory pathways (IL1B, IL6, TNF, FOS), angiogenesis (IL1B, IL6, LEP, TNF, EGFR, FOS), and other processes.

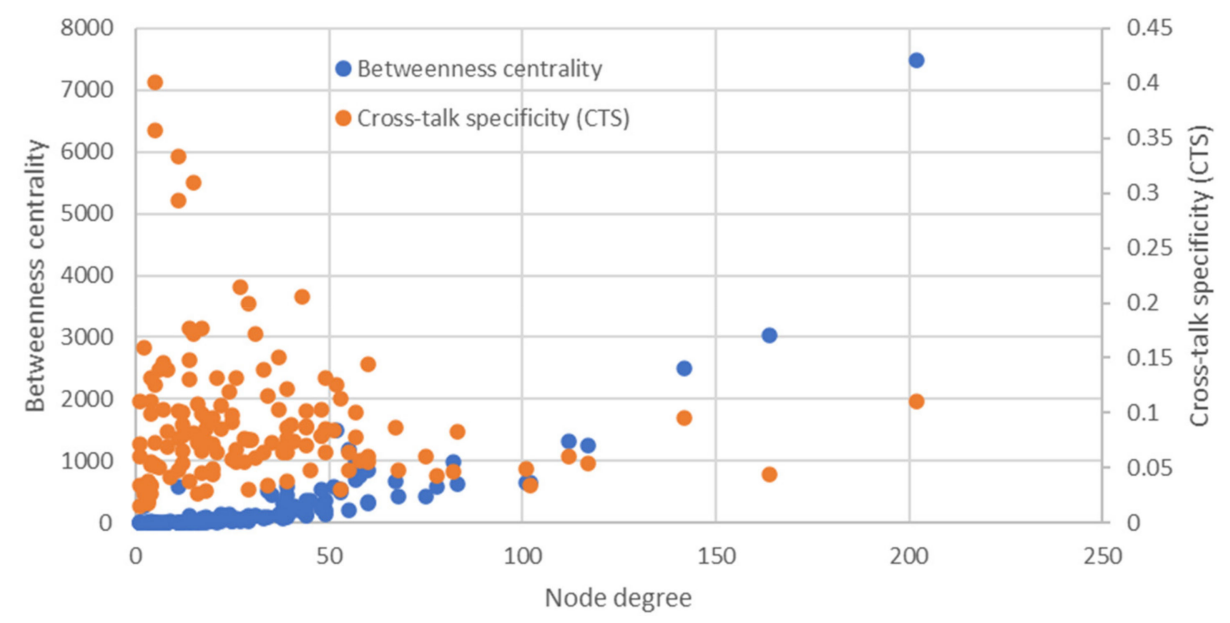

Figure 2. The distribution of node connectivity, betweenness centrality and cross-talk specificity (CTS) values in the hypoglycemia network.

Ten genes (GPR142, MBOAT4, SLC5A4, IGFBP6, PPY, G6PC1, SLC2A2, GYS2, GCGR and $A Q P 7)$ demonstrated the highest cross-talk specificity values (Figure 2, Table S3). These genes had a relatively large number of links in the considered gene network having a small number of links in the global human gene network. Among the products, isletenriched G protein-coupled receptor (GPR142) was discussed as a potential target for 
the treatment of type 2 diabetes as it stimulates glucose-dependent insulin secretion [36]. Overproduction of insulin-like growth factor-binding protein 6 (IGFBP6) was reported to be a marker of non-islet tumor-induced hypoglycemia [37]. Mutations in the genes of glucose-6-phosphatase (G6PC1), glycogen synthase 2 (GYS2) and aquaporin 7 (AQP7) may cause fasting hypoglycemia due to impaired liver metabolism [38,39]. Glucagon receptor (GCGR), pancreatic polypeptide Y (PPY), glucose transporter 2 (GLUT2, SLC2A2) and ghrelin o-acyltransferase (MBOAT4) could be involved in the counterregulatory response to hypoglycemia [40-43].

An analysis performed with the DAVID web-tool [29] identified insulin secretion, glucose homeostasis, up-regulation of gene transcription, regulation of neuron death, apoptosis and nitric oxide biosynthesis among the most overrepresented Gene Ontology (GO) biological processes (Table S4, Table 3).

Table 3. Top 10 GO biological processes most overrepresented for hypoglycemia-related genes.

\begin{tabular}{|c|c|c|}
\hline Gene Ontology Biological Process & Genes & $\begin{array}{l}p \text {-Values with Bonferroni } \\
\text { Correction }\end{array}$ \\
\hline GO:0050796 regulation of insulin secretion & $\begin{array}{c}\text { ABCC8, ARNTL, CACNA1C, CPT1A, GCG, GCK, } \\
\text { GIP, GLP1R, HNF1A, HNF4A, IL1B, KCNJ11, LEP, } \\
\text { SLC16A1, SLC2A1, SLC2A2, TNF }\end{array}$ & $2.66 \times 10^{-16}$ \\
\hline GO:0042593 glucose homeostasis & $\begin{array}{c}\text { ADIPOQ, AKT1, G6PC1, GCG, GCGR, GCK, } \\
\text { HNF1A, HNF4A, IL6, INS, INSR, LEP, LEPR, PDK4, } \\
\text { SIRT6, SLC16A1, SLC30A8, TCF7L2 } \\
\text { ADCYAP1, ADRB2, AKT1, ARNTL, CD40, CSF3, }\end{array}$ & $2.16 \times 10^{-13}$ \\
\hline $\begin{array}{l}\text { GO:0045944 positive regulation of } \\
\text { transcription from RNA polymerase } \\
\text { II promoter }\end{array}$ & $\begin{array}{c}\text { DDIT3, EDN1, EGFR, FGF2, FOS, FOXO1, HNF1A, } \\
\text { HNF4A, IGF1, IL1B, IL6, NAMPT, NFE2L2, NOS1, } \\
\text { NOTCH1, NR3C1, PARK7, PPARA, PROP1, PTH, } \\
\text { SERPINE1, SIRT1, SOX17, TCF7L2, TNF, TRAF6, } \\
\text { UCN, VEGFA, WWOX }\end{array}$ & $8.36 \times 10^{-10}$ \\
\hline $\begin{array}{c}\text { GO:1901215 negative regulation of } \\
\text { neuron death }\end{array}$ & $\begin{array}{c}\text { AKT1, CHGA, CSF3, EPO, FGF21, IL6, PARK7, } \\
\text { PPARA, SIRT1, TIGAR, UCN }\end{array}$ & $1.35 \times 10^{-09}$ \\
\hline GO:0015758 glucose transport & $\begin{array}{c}A K T 1, \text { EDN1, G6PC1, GCK, GH1, HK1, INS } \\
\text { SLC2A1, SLC2A2, SLC5A1 }\end{array}$ & $8.35 \times 10^{-09}$ \\
\hline GO:0006006 glucose metabolic process & $\begin{array}{c}\text { ADIPOQ, AKT1, AKT2, CPT1A, H6PD, IGF2, INS, } \\
\text { KCNJ11, LEP, PDK4, PGM1, TNF }\end{array}$ & $1.30 \times 10^{-08}$ \\
\hline $\begin{array}{c}\text { GO:0045725 positive regulation of glycogen } \\
\text { biosynthetic process }\end{array}$ & AKT1, AKT2, GCK, IGF1, IGF2, INS, INSR, PTH & $2.58 \times 10^{-08}$ \\
\hline $\begin{array}{l}\text { GO:0043066 negative regulation of } \\
\text { apoptotic process }\end{array}$ & $\begin{array}{c}\text { AKT1, ALB, ANGPTL4, AVP, CDKN1A, EGFR, } \\
\text { FOXO1, GCG, IGF1, IGF1R, IL6, LEP, PARK7, PRNP, } \\
\text { PROP1, SIAH2, SIRT1, SOD2, TRAF6, UCN, UCP2, } \\
\text { VEGFA, VHL }\end{array}$ & $3.92 \times 10^{-08}$ \\
\hline $\begin{array}{c}\text { GO:0045429 positive regulation of nitric oxide } \\
\text { biosynthetic process }\end{array}$ & $\begin{array}{c}\text { AGTR2, AKT1, EDN1, EGFR, IL1B, IL6, INS, INSR, } \\
\text { SOD2, TNF }\end{array}$ & $1.14 \times 10^{-07}$ \\
\hline $\begin{array}{c}\text { GO:0046326 positive regulation of } \\
\text { glucose import }\end{array}$ & $\begin{array}{c}\text { ADIPOQ, AKT1, AKT2, FGF21, IGF1, INS, INSR, } \\
\text { NFE2L2, PTH }\end{array}$ & $1.66 \times 10^{-07}$ \\
\hline
\end{tabular}

At the next step, we performed the enrichment analysis of anatomical structures mapped to genes by expression patterns by Bgee web-tool [30]. The central nervous system, connective tissue, muscles, cardiovascular system, gastrointestinal tract, female reproductive system, abdominal adipose tissue, kidney, and pancreas turned out to be the most overrepresented entities where the greatest number of hypoglycemia-related genes expresses (Table S5).

The obtained results clearly indicate that hypoglycemia can regulate a lot of hub genes affecting the key biological processes in the targeted organs. 


\subsection{Comparative Analysis of the Gene Networks of Hypoglycemia and Diabetic Vascular Disease}

Taking into account the clinical association between hypoglycemia and vascular disease in diabetes, we matched the gene network of hypoglycemia with the gene networks of diabetic macrovascular and microvascular complications.

With the instruments of the ANDSystem, we have identified 494 genes/proteins associated with cardiovascular disease, of which 47 were also present in the gene network of hypoglycemia (Table S6). In addition, genes related to hypoglycemia were significantly overrepresented in the network of cardiovascular disease $\left(p\right.$-value $\left.10^{-39}\right)$. The network of diabetic retinopathy contained 424 genes/proteins, fifty of them were also present in the network of hypoglycemia (Table S7). The network of diabetic nephropathy consisted of 685 genes/proteins; among them, 62 molecules shared with the hypoglycemia network (Table S8). One hundred and thirty genes/proteins made up the network of diabetic neuropathy; among them, 22 were found in the gene network of hypoglycemia (Table S9). In all networks of microvascular complications, the genes related to hypoglycemia were significantly overrepresented, with $p$-values $10^{-45}, 10^{-53}$ and $10^{-23}$ respectively.

According to the AmiGO2 database (http://geneontology.org/), 104 human genes are associated with microvascular endothelial cells (Table S10). Of these, 15 were present in the hypoglycemic gene network, including CD36 molecule (CD36), claudin 5 (CLDN5), epidermal growth factor receptor (EGFR), fibroblast growth factor 2 (FGF2), insulin receptor (INSR), leptin (LEP), leptin receptor (LEPR), notch 1 (NOTCH1), solute carrier family 16 member 1 (SLC16A1), solute carrier family 22 member 1 (SLC22A1), solute carrier family 2 member 1 (SLC2A1), solute carrier family 5 member 1 (SLC5A1), tumor necrosis factor (TNF), TNF receptor-associated factor 6 (TRAF6), and vascular endothelial growth factor A (VEGFA). The chance of finding so many genes for random reasons is extremely low ( $p$-value $10^{-15}$ ).

Figure 3 represents a Venn diagram showing the intersection of the gene lists of the networks of hypoglycemia, cardiovascular disease, diabetic retinopathy, diabetic nephropathy, and diabetic neuropathy. It turned out that 14 genes were mutual for all analyzed gene networks. The products of these genes encode insulin (INS) and insulin receptor (INSR), endothelin-1 (EDN1), erythropoietin (EPO), adiponectin (ADIPOQ), interleukin-1 $\beta$ (IL1B), interleukin-6 (IL6), tumor necrosis factor $\alpha$ (TNF), glucagon-like peptide-1 receptor (GLP1R), insulin-like growth factor-1 (IGF1), vascular endothelial growth factor A (VEGFA), C-reactive protein (CRP), nuclear factor, erythroid 2 like 2 (NFE2L2) and neuropeptide $Y(N P Y)$. A wide range of biological activities of these molecules is consistent with the concept of their key role in the pathophysiology of diabetic vascular complications [44-56].

In addition, the genes of neuropilin 1 (NRP1), adenylate cyclase-activating polypeptide 1 (ADCYAP1) and fibroblast growth factor 2 (FGF2) were mutual for the networks of hypoglycemia and all microvascular complications. Neuropilin-1 is a membrane-bound receptor for vascular endothelial growth factor and semaphorin family members, it is important for angiogenesis, axon guidance, cell survival, migration, and invasion. The role of neuropilin-1 in diabetic complications is discussed [57,58]. Adenylate cyclaseactivating polypeptide 1 , the product of $A D C Y A P 1$ gene, is involved in neuroendocrine stress response; in pancreatic islets, it may produce a glucose-sensitive effect and decrease insulin levels required to control hyperglycemia [59]. Fibroblast growth factor 2, being involved in cell growth, angiogenesis, atherogenesis, wound healing and other processes, is implicated in the development of diabetic nephropathy [60], diabetic retinopathy [61], diabetic neuropathy [62], and coronary artery disease [63].

For the networks of hypoglycemia and vascular complications, overrepresented Gene Ontology biological processes have been identified using the DAVID web-tool (Table S11). Eleven processes were overrepresented simultaneously for the gene sets of all considered conditions (Table 4). Among these processes, there were those involved in glucose homeostasis, regulation of nitric oxide biosynthesis, muscle cell proliferation, DNA replication and apoptosis, regulation of protein kinase B signaling, ERK1 and ERK2 cascade, and others. 


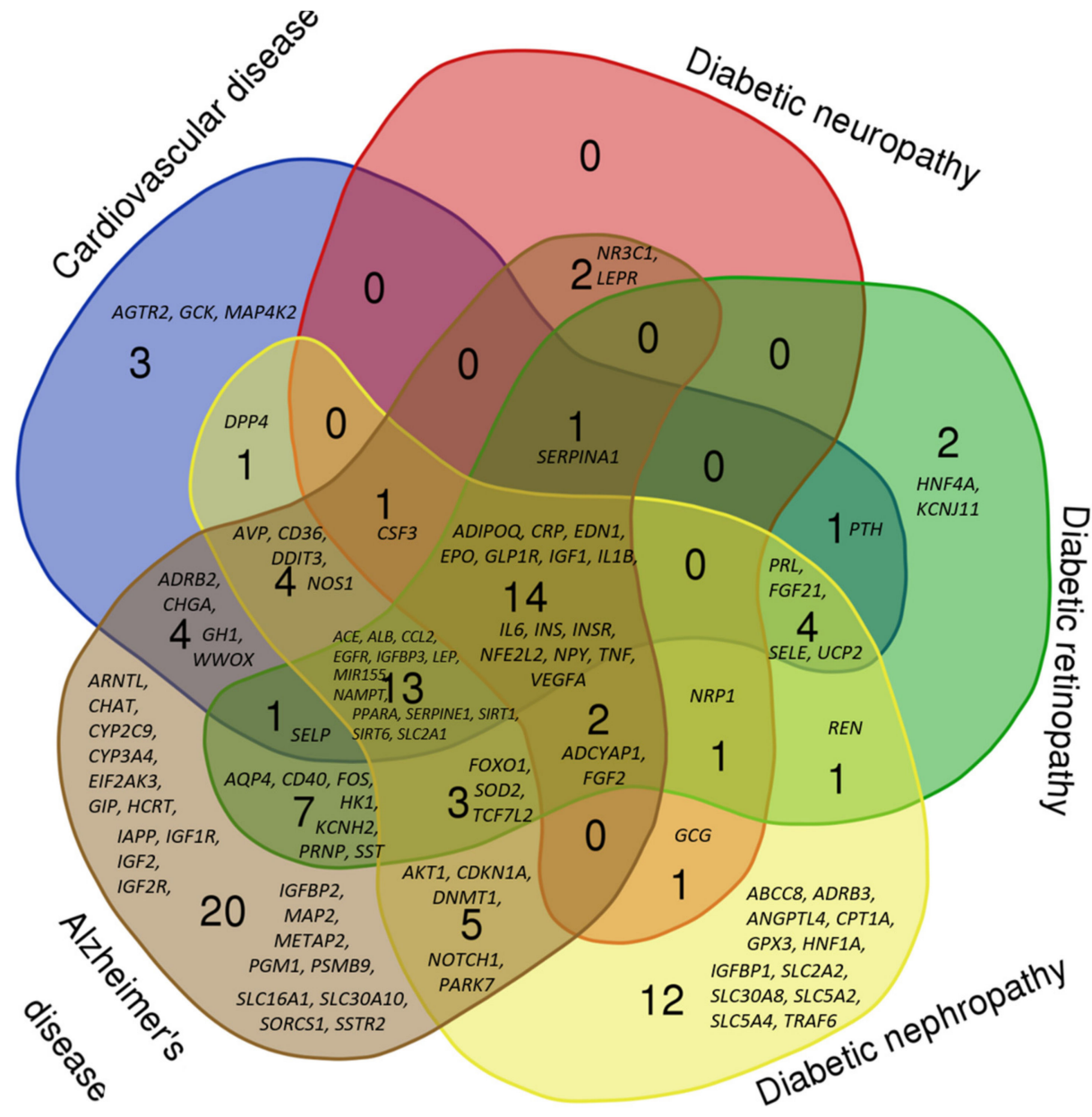

Figure 3. Venn diagram of intersection of gene sets associated simultaneously with hypoglycemia and cardiovascular disease, diabetic neuropathy, diabetic retinopathy, diabetic nephropathy, and Alzheimer's disease.

Table 4. Gene ontology biological processes that are overrepresented simultaneously for the gene sets associated with hypoglycemia and cardiovascular disease, diabetic neuropathy, diabetic retinopathy, diabetic nephropathy, and AD.

\begin{tabular}{|c|c|c|c|c|c|}
\hline \multirow[b]{2}{*}{ Gene Ontology Biological Process } & \multicolumn{5}{|c|}{ Enrichment Significance, $p$-Value with Bonferroni Correction } \\
\hline & Cardiovascular Disease & $\begin{array}{l}\text { Diabetic } \\
\text { Neuropathy }\end{array}$ & $\begin{array}{c}\text { Diabetic } \\
\text { Retinopathy }\end{array}$ & Diabetic Nephropathy & AD \\
\hline $\begin{array}{l}\text { GO:0045429 positive regulation of } \\
\text { nitric oxide biosynthetic process }\end{array}$ & $2.05 \times 10^{-08}$ & $1.29 \times 10^{-06}$ & $3.63 \times 10^{-08}$ & $3.29 \times 10^{-09}$ & $2.21 \times 10^{-08}$ \\
\hline $\begin{array}{l}\text { GO:0008284 positive regulation of } \\
\text { cell proliferation }\end{array}$ & $1.13 \times 10^{-08}$ & $1.49 \times 10^{-06}$ & $4.81 \times 10^{-07}$ & $5.07 \times 10^{-10}$ & $2.77 \times 10^{-08}$ \\
\hline $\begin{array}{c}\text { GO:0045944 positive regulation of } \\
\text { transcription from RNA } \\
\text { polymerase II promoter }\end{array}$ & $2.38 \times 10^{-06}$ & $6.50 \times 10^{-05}$ & $8.74 \times 10^{-09}$ & $1.49 \times 10^{-10}$ & $6.93 \times 10^{-12}$ \\
\hline $\begin{array}{c}\text { GO:0051897 positive regulation of } \\
\text { protein kinase B signaling }\end{array}$ & $1.02 \times 10^{-04}$ & $3.99 \times 10^{-05}$ & $4.67 \times 10^{-06}$ & $2.32 \times 10^{-08}$ & $5.76 \times 10^{-09}$ \\
\hline $\begin{array}{l}\text { GO:0046326 positive regulation of } \\
\text { glucose import }\end{array}$ & $1.67 \times 10^{-07}$ & $3.65 \times 10^{-05}$ & $2.74 \times 10^{-07}$ & $1.37 \times 10^{-06}$ & $3.24 \times 10^{-04}$ \\
\hline $\begin{array}{c}\text { GO:0045740 positive regulation of } \\
\text { DNA replication }\end{array}$ & $9.77 \times 10^{-05}$ & $1.47 \times 10^{-04}$ & $1.49 \times 10^{-04}$ & $5.77 \times 10^{-04}$ & $4.78 \times 10^{-05}$ \\
\hline $\begin{array}{l}\text { GO:0048661 positive regulation of } \\
\text { smooth muscle cell proliferation }\end{array}$ & $6.05 \times 10^{-04}$ & $6.33 \times 10^{-04}$ & $2.17 \times 10^{-05}$ & $5.54 \times 10^{-08}$ & $1.36 \times 10^{-05}$ \\
\hline $\begin{array}{l}\text { GO:0050731 positive regulation of } \\
\text { peptidyl-tyrosine phosphorylation }\end{array}$ & $8.86 \times 10^{-05}$ & $4.33 \times 10^{-07}$ & 0.004386 & $2.44 \times 10^{-05}$ & $4.72 \times 10^{-06}$ \\
\hline $\begin{array}{c}\text { GO:0045840 positive regulation of } \\
\text { mitotic nuclear division }\end{array}$ & $7.25 \times 10^{-04}$ & $2.00 \times 10^{-05}$ & 0.001034 & 0.003167 & $1.52 \times 10^{-04}$ \\
\hline GO:0042593 glucose homeostasis & $3.09 \times 10^{-04}$ & 0.005116 & $1.71 \times 10^{-05}$ & $1.26 \times 10^{-07}$ & $1.04 \times 10^{-06}$ \\
\hline $\begin{array}{c}\text { GO:0070374 positive regulation of } \\
\text { ERK1 and ERK } 2 \text { cascade }\end{array}$ & 0.007662 & $9.15 \times 10^{-07}$ & $1.72 \times 10^{-06}$ & $3.86 \times 10^{-08}$ & 0.001765 \\
\hline
\end{tabular}


Thus, the comparative analysis of the gene networks of hypoglycemia and diabetic vascular complications indicates common molecular and cellular mechanisms underlying these disorders. The deteriorating effect of hypoglycemia in diabetic vascular disease can be mediated through a wide range of genes encoding hormones, receptors, cytokines, growth factors, and some other proteins that modulate not only glucose homeostasis but also the cell cycle, proliferation and intracellular signaling pathways.

\subsection{Comparative Analysis of the Gene Networks of Hypoglycemia, Cognitive Decline and $A D$}

At the next step, we matched the gene network of hypoglycemia with the network of cognitive decline and AD. The gene network of cognitive decline is presented in Table S12. It contains 302 genes/proteins, of which 22 were also participating in hypoglycemia gene network. Among the mutual genes, we have identified those encoding insulin (INS), islet amyloid polypeptide (IAPP), somatostatin (SST), leptin (LEP), adiponectin (ADIPOQ), erythropoietin (EPO), interleukin-6 (IL6), tumor necrosis factor $\alpha$ (TNF), AKT serine/threonine kinase 1 (AKT1) and C-C motif chemokine ligand 2 (CCL2), insulin-like growth factor 1 (IGF1), insulin-like growth factor-binding protein 3 (IGFBP3), epidermal growth factor receptor (EGFR), adenylate cyclase-activating polypeptide 1 (ADCYAP1), albumin $(A L B)$, angiotensin I converting enzyme $(A C E)$, aquaporin $4(A Q P 4)$, C-reactive protein $(C R P)$, prion protein (PRNP), serpin family A member 1 (SERPINA1), serpin family E member 1 (SERPINE1), and sirtuin 1 (SIRT1). According to the hypergeometric distribution, the genes associated with hypoglycemia were overrepresented in the cognitive decline network ( $p$-value $10^{-15}$ ).

A growing body of evidence indicates a link between impaired glucose metabolism in the central nervous system and $\mathrm{AD}[17,64-66]$. It was shown that reduced glucose availability in the brain directly triggers behavioral deficits by promoting the development of tau neuropathology and synaptic dysfunction $[17,18]$. Therefore, in this work, we have reconstructed a gene network of $\mathrm{AD}$ and matched it with that of hypoglycemia. The network of AD included 1622 genes/proteins (Table S13). Of these molecules, 77 were also involved in the network of hypoglycemia and 22 molecules were associated with hypoglycemia, cognitive decline and AD. It should be noted that genes/proteins related to hypoglycemia were significantly overrepresented in the AD network ( $p$-value $10^{-45}$ ).

Analysis of the overrepresentation of GO processes associated with AD network (Table S11) revealed the same biological processes that have been identified for hypoglycemia, cardiovascular disease and microvascular diabetic complications (Table 4). In addition, the negative regulation of neuron death was recognized among the top processes related to the AD network. Therefore, it can be assumed that hypoglycemia triggers a number of molecular and cellular events that are universal for vascular and neurological complications.

It was interesting to match the relations of hypoglycemia and AD with associated genes (Table 5, Table S14). Genetic variations that modulate risk of both disorders were found in ADRB2 [67,68], and PSMB9 [69,70]. Mutations of HK1, IGF1R, INSR, NR3C1, SIRT6, and WWOX were associated with hypoglycemia [71-76] and these genes were found to be down-regulated in AD [77-82]. Eleven genes (CCL2, CD40, CDKN1A, CYP3A4, FOS, HCRT, IGFBP2, IL6, PARK7, SERPINA1, and VEGFA) were up-regulated by hypoglycemia and were found to be also up-regulated in AD. Another group of genes (MAP2, METAP2, NFE2L2, SELP, SST, and VEGFA) was down-regulated by hypoglycemia and also downregulated in $\mathrm{AD}$. 
Table 5. Combined analysis of the genes related to hypoglycemia and AD.

\begin{tabular}{|c|c|c|c|c|}
\hline Hypoglycemia & $\begin{array}{c}\text { Genes Up-Regulated by } \\
\text { AD }\end{array}$ & $\begin{array}{c}\text { Genes Down- } \\
\text { Regulated by AD }\end{array}$ & $\begin{array}{l}\text { Genes with SNPs } \\
\text { Increasing AD Risk }\end{array}$ & $\begin{array}{l}\text { Genes with Other } \\
\text { Relations with AD }\end{array}$ \\
\hline Genes up-regulated by hypoglycemia & $\begin{array}{c}\text { CCL2, CD40, CDKN1A, } \\
\text { CYP3A4, FOS, HCRT, } \\
\text { IGFBP2, IL6, PARK7, } \\
\text { SERPINA1, VEGFA }\end{array}$ & $\begin{array}{l}\text { AVP, EDN1, LEPR, } \\
\text { SLC2A1, VEGFA }\end{array}$ & CHAT, NPY, PRNP & $\begin{array}{c}\text { ADIPOQ, ALB, AQP4, } \\
\text { CHGA, CRP, DDIT3, } \\
\text { EIF2AK3, EPO, GH1, } \\
\text { GIP, NOS1, } \\
\text { SERPINE1, SOD2 }\end{array}$ \\
\hline Genes down-regulated by hypoglycemia & $V E G F A$ & $\begin{array}{c}\text { MAP2, METAP2, } \\
\text { NFE2L2, SELP, SST, } \\
\text { VEGFA }\end{array}$ & DNMT1 & \\
\hline $\begin{array}{l}\text { Genes with SNPs increasing } \\
\text { hypoglycemia risk }\end{array}$ & CYP2C9 & $\begin{array}{c}\text { HK1, IGF1R, INSR, } \\
\text { NR3C1, SIRT6, } \\
\text { WWOX }\end{array}$ & ADRB2, PSMB9 & $\begin{array}{c}\text { ACE, IGF2R, PGM1, } \\
\text { SORCS1, TCF7L2 }\end{array}$ \\
\hline $\begin{array}{c}\text { Genes with other relations with } \\
\text { hypoglycemia }\end{array}$ & $\begin{array}{l}\text { IGFBP3, IGF2, MIR155, } \\
\text { NOTCH1, TNF }\end{array}$ & $\begin{array}{l}\text { NAMPT, SIRT1, } \\
\text { SLC30A10, SSTR2 }\end{array}$ & $\begin{array}{l}\text { AKT1, ARNTL, CD36, } \\
\text { IL1B, PPARA }\end{array}$ & $\begin{array}{c}\text { ADCYAP1, CSF3, } \\
\text { EGFR, FGF2, FOXO1, } \\
\text { GLP1R, IAPP, IGF1, } \\
\text { INS, KCNH2, LEP, } \\
\text { SLC16A1 }\end{array}$ \\
\hline
\end{tabular}

A number of analyzed genes were suggested as potential targets for AD treatment, including ADIPOQ [83], AQP4 [84], CCL2 [85], CRP [86], EIF2AK3 [87], EPO [88], IGF1 [89], IGF1R [90,91], IGF2 [92,93], IGFBP2 [94], IL6 [95], NFE2L2 [96,97], NOS1 [98], NPY [99,100], PARK7 [101], SERPINE1 [102], SIRT1 [103], SIRT6 [81,104], SLC2A1 [105,106], TNF [107,108], VEGF and VEGFR [109]. The role of these molecules in hypoglycemia-induced brain dysfunction needs further research.

Thus, the obtained results demonstrate significant similarity in the gene networks of hypoglycemia, cardiovascular disease, diabetic microvascular complications and AD. This is consistent with clinical evidence that cognitive dysfunction is associated with severe hypoglycemia and the presence of micro- and/or macrovascular diseases in subjects with diabetes [110]. The revealed universality of molecular events and biological processes in hypoglycemia, cardiovascular diseases and AD contributes to a further understanding of the mechanisms of comorbidity in diabetes.

\subsection{Study Limitations}

Our study is not without limitations. As the ANDSystem utilizes an automatic text mining-based approach for network reconstruction, we cannot exclude that some relevant information has been missed. The study is a hypothesis-generating one. The role of identified genes/proteins, as well as biological processes, in hypoglycemia and associated events, needs further experimental testing.

\section{Materials and Methods}

\subsection{The ANDSystem Tool and Network Analysis}

The reconstruction of gene networks was performed using the ANDSystem, version: 20.0413b646_2021 (ICG SB RAS, Novosibirsk, Russia). The ANDSystem is available online: http:/ / www-bionet.sscc.ru/and/cell/ (accessed on 8 September 2021). The main modules of ANDSystem are the knowledge extraction module, the ANDCell knowledge base and the user interface ANDVisio. The knowledge extraction module is based on textmining technology utilizing the dictionaries of object names and semantic templates. The preparation of dictionaries is based on the automatic extraction of names and synonyms of biological objects from external databases and the texts of scientific publications. The semantic templates are the structured records listing the object types, dictionaries, regular expressions for text analysis and descriptions of the interaction semantics. As a result of the triggering of a linguistic template, interactions between objects from dictionaries are revealed. Linguistic templates generalize interactions by 24 types (for example, expression regulation, protein-protein interaction, association, etc.), and also define the organism in which this interaction is found. The knowledge extraction module allows the filling of the 
ANDCell knowledge base. It is a prebuild knowledge base which contains information about more than 20 million interactions between biological objects. The update of the information stored in the ANDCell is performed annually. Both the knowledge extraction module and the ANDCell knowledge base are located on a server. The ANDVisio is a client module allowing the user to query the ANDCell knowledge base. Based on the user queries the molecular-genetic networks could be reconstructed, analyzed and visualized as bipartite graphs. Biological objects are shown as nodes and interactions between them are represented as edges of the graph. The ANDSystem could be used for building in an automatic manner the associative molecular (gene) networks describing phenotypes, diseases and biological processes important for bio-medical tasks [22-24].

As the ANDVisio allows to analyze the molecular-genetic networks it was applied to find the node connectivity and betweenness centrality coefficients of nodes in the hypoglycemia gene network. These parameters were calculated with function "Statistics" of the "Analysis" section of ANDVisio. The cross-talk specificity (CTS) values were calculated by ANDVisio function "Intelligent Filtration." CTS was calculated according to the formula: $\mathrm{CTS}=\mathrm{K}_{\mathrm{i}} / \mathrm{M}_{\mathrm{i}}$, where $\mathrm{K}_{\mathrm{i}}$ is a number of links that the $\mathrm{i}$ gene has in the analyzed gene network; $\mathrm{M}_{\mathrm{i}}$ is a number of links that the $\mathrm{i}$ gene has in the global human gene network of ANDSystem [22-24].

\subsection{The Gene Set Enrichment Analysis}

The gene set enrichment analysis is broadly used to identify groups of genes that are over-/under-represented in a large gene set and that can possibly be associated with studied conditions based on statistical approaches, for example, using the hypergeometric distribution.

The gene set enrichment analysis web-tool DAVID (Available online: https:/ / david.ncifcrf. gov/home.jsp (accessed on 31 August 2021)), version 6.8 (LHRI, Frederick, MD, USA) [29] was used to find the overrepresented Gene Ontology biological processes. The parameters were set as follows: organism, "Homo sapiens"; Gene_Ontology,"GOTERM_BP_DIRECT.” The statistically significant enrichment of a Gene Ontology biological process was considered when the $p$-values with Bonferroni correction were lower than 0.01 .

The enrichment analysis of anatomical structures mapped to genes by expression patterns was performed by Bgee (Available online: https:/ /bgee.org/ (accessed on 27 April 2021)) function TopAnat [30].

The assessment of the overrepresentation of hypoglycemia genes in the networks of cardiovascular disease, diabetic nephropathy, diabetic retinopathy, diabetic neuropathy, cognitive decline and $\mathrm{AD}$ was performed according to the hypergeometric distribution by the "hypergeom.sf" function of the "scipy" library of the Python programming language [111].

\subsection{The Databases AmiGO2 and GeneCards}

The GeneCards ${ }^{\circledR}$ : The Human Gene Database (Available online: https://www. genecards.org/ (accessed on 16 September 2021)) stores information on gene molecular function. It was queried to check the molecular function of identified genes associated with hypoglycemia.

The AmiGO2 database (Available online: http:/ / geneontology.org/ (accessed on 4 September 2021)) [112] is a web-based tool for searching and browsing the Gene Ontology which is the world's largest knowledge base containing the information on gene functions. The AmiGO2 database was used to find the genes associated with microvascular endothelial cells.

\subsection{Manual Classification of Links between Genes and Hypoglycemia}

Table 2 was built based on information about relations between hypoglycemia and genes automatically extracted from PubMed publications by ANDSystem. The extracted sentences presented in Table S1 were manually analyzed and the links between genes 
and hypoglycemia were classified in 6 groups: "Gene expression is up-regulated by hypoglycemia," "Gene expression is down-regulated by hypoglycemia," "Molecules with hypoglycemic or antihyperglycemic activity," "Protective effect against hypoglycemia and/or response to hypoglycemia," "SNPs associated with the risk of hypoglycemia," and "Other links."

\subsection{The Venn Diagram}

The Venn diagram demonstrating the interactions of hypoglycemia-related genes from the gene networks of cardiovascular disease, diabetic nephropathy, diabetic retinopathy, diabetic neuropathy, and Alzheimer's disease was made by the "Bioinformatics \& Evolutionary Genomics" resource available online: http:/ /bioinformatics.psb.ugent.be/ webtools/Venn/ (accessed on 7 September 2021).

\section{Conclusions}

Hypoglycemia is a trigger for a number of complications and comorbidities in diabetes, including cardiovascular events, microvascular diabetic complications, cognitive dysfunction, and AD. In this work, we reconstructed and matched to each other the gene networks of hypoglycemia and the above-mentioned disorders using the ANDSystem that operates text-mining technology.

There were 141 genes/proteins in the hypoglycemia-associated network. Among them, INS, IL6, LEP, TNF, IL1B, EGFR, and FOS were the principal central hubs, meanwhile, GPR142, MBOAT4, SLC5A4, IGFBP6, PPY, G6PC1, SLC2A2, GYS2, GCGR and AQP7 were the most specific, according to the CTS criterion. The enrichment analysis of GO biological processes showed that regulation of insulin secretion, glucose homeostasis, apoptosis, nitric oxide biosynthesis and cell signaling are significantly enriched for hypoglycemia. The anatomical structures that are overrepresented among those associated with hypoglycemia genes are the central nervous system, muscles, aorta, connective tissue, and others.

In the next step, we built the gene networks of diabetic complications and comorbidities for which hypoglycemia is considered a trigger. A step-by-step comparison of the hypoglycemic gene network with that for cardiovascular diseases, diabetic retinopathy, diabetic nephropathy, diabetic neuropathy, cognitive decline and AD showed that hypoglycemia-related genes are overrepresented for all hypoglycemia-triggered conditions according to the hypergeometric distribution. It was suggested that 14 genes (ADIPOQ, CRP, EDN1, EPO, GLP1R, IGF1, IL1B, IL6, INS, INSR, NFE2L2, NPY, TNF, and VEGFA) can significantly contribute to the development of hypoglycemia comorbidities. It turned out that genes associated with hypoglycemia, macro- and microvascular diabetes complications and Alzheimer's disease are involved in nitric oxide biosynthesis, glucose homeostasis, ERK1 and ERK2 cascade, smooth muscle cell proliferation, and some others. In AD, hypoglycemia also regulates the neuron death process. Among the genes associated with both $\mathrm{AD}$ and hypoglycemia, we have identified those that are promising for further study as drug targets (CCL2, CD40, CDKN1A, CYP3A4, FOS, HCRT, IGFBP2, IL6, MAP2, METAP2, NFE2L2, PARK7, SELP, SST, VEGFA and others).

The obtained results expand the understanding of the molecular mechanisms of the deteriorating effect of hypoglycemia on the targeted organs in diabetes. Influencing the expression of many genes and intensity of physiological processes, hypoglycemia can play an important role in the promotion of diabetes-associated vascular disease and cognitive dysfunction.

Supplementary Materials: The following are available online at https:/ /www.mdpi.com/article/10 .3390/ijms222212419/s1.

Author Contributions: Conceptualization, V.V.K. and O.V.S.; methodology, V.V.K. and O.V.S.; investigation, O.V.S.; writing — original draft preparation, V.V.K. and O.V.S.; writing—review and editing, V.V.K. and O.V.S.; visualization, O.V.S.; supervision, V.V.K. All authors have read and agreed to the published version of the manuscript. 
Funding: This research was funded by Russian Science Foundation, grant number 20-15-00057.

Institutional Review Board Statement: The study was conducted according to the guidelines of the Declaration of Helsinki, and approved by the Ethics Committee of the RICEL-Branch of IC\&G SB RAS (protocol No. 158, date of approval 1 June 2020).

Informed Consent Statement: Not applicable.

Data Availability Statement: The data supported reported results are available in Supplementary Materials to this article.

Acknowledgments: We acknowledge Vladimir Ivanisenko (ICG SB RAS, Novosibirsk, Russia) and Pavel Demenkov (ICG SB RAS, Novosibirsk, Russia) for the advices concerning bioinformatics approaches valuable for the performed analysis.

Conflicts of Interest: The authors declare no conflict of interest. The funders had no role in the design of the study; in the collection, analyses, or interpretation of data; in the writing of the manuscript, or in the decision to publish the results.

\section{Abbreviations}

$\begin{array}{ll}\text { AD } & \text { Alzheimer's disease } \\ \text { CTS } & \text { cross-talk specificity } \\ \text { ERK } & \text { extracellular signal-regulated kinase } \\ \text { GO } & \text { Gene Ontology } \\ \text { SNP } & \text { single nucleotide polymorphism }\end{array}$

\section{References}

1. Heller, S.R.; Peyrot, M.; Oates, S.K.; Taylor, A.D. Hypoglycemia in patient with type 2 diabetes treated with insulin: It can happen. BMJ Open Diabetes Res. Care 2020, 8, e001194. [CrossRef]

2. Shi, L.; Fonseca, V.; Childs, B. Economic burden of diabetes-related hypoglycemia on patients, payors, and employers. J. Diabetes Complicat. 2021, 35, 107916. [CrossRef] [PubMed]

3. McCoy, R.G.; Van Houten, H.K.; Ziegenfuss, J.Y.; Shah, N.D.; Wermers, R.A.; Smith, S.A.; Gruden, G.; Barutta, F.; Chaturvedi, N.; Schalkwijk, C.; et al. Increased Mortality of Patients with Diabetes Reporting Severe Hypoglycemia. Diabetes Care 2012, 35 , 1897-1901. [CrossRef] [PubMed]

4. $\quad$ Davis, S.N.; Duckworth, W.; Emanuele, N.; Hayward, R.A.; Wiitala, W.L.; Thottapurathu, L.; Reda, D.J.; Reaven, P.D.; Investigators of the Veterans Affairs Diabetes Trial. Effects of Severe Hypoglycemia on Cardiovascular Outcomes and Death in the Veterans Affairs Diabetes Trial. Diabetes Care 2018, 42, 157-163. [CrossRef] [PubMed]

5. Malik, A.H.; Yandrapalli, S.; Aronow, W.S.; Jain, D.; Frishman, W.H.; Panza, J.A.; Cooper, H.A. Severe Hypoglycemia and Risk of Subsequent Cardiovascular Events: Systematic Review and Meta-Analysis of Randomized Controlled Trials. Cardiol. Rev. 2020, 28, 244-249. [CrossRef] [PubMed]

6. Rana, J.S.; Moffet, H.H.; Liu, J.Y.; Karter, A.J. Severe Hypoglycemia and Risk of Atherosclerotic Cardiovascular Disease in Patients with Diabetes. Diabetes Care 2021, 44, e40-e41. [CrossRef] [PubMed]

7. Standl, E.; Stevens, S.R.; Lokhnygina, Y.; Bethel, M.A.; Buse, J.B.; Gustavson, S.M.; Maggioni, A.P.; Mentz, R.J.; Hernandez, A.F.; Holman, R.R.; et al. Confirming the Bidirectional Nature of the Association Between Severe Hypoglycemic and Cardiovascular Events in Type 2 Diabetes: Insights From EXSCEL. Diabetes Care 2019, 43, 643-652. [CrossRef] [PubMed]

8. Tanaka, S.; Kawasaki, R.; Tanaka-Mizuno, S.; Iimuro, S.; Matsunaga, S.; Moriya, T.; Ishibashi, S.; Katayama, S.; Ohashi, Y.; Akanuma, Y.; et al. Severe hypoglycaemia is a major predictor of incident diabetic retinopathy in Japanese patients with type 2 diabetes. Diabetes Metab. 2017, 43, 424-429. [CrossRef]

9. Diallo, A.M.; Novella, J.-L.; Lukas, C.; Souchon, P.-F.; Dramé, M.; François, M.; Decoudier, B.; Barraud, S.; Salmon, A.-S.; Ancelle, D.; et al. Early predictors of diabetic retinopathy in type 1 diabetes: The Retinopathy Champagne Ardenne Diabète (ReCAD) study. J. Diabetes Complicat. 2018, 32, 753-758. [CrossRef]

10. Yun, J.-S.; Park, Y.-M.; Han, K.; Kim, H.-W.; Cha, S.-A.; Ahn, Y.-B.; Ko, S.-H. Severe hypoglycemia and the risk of end stage renal disease in type 2 diabetes. Sci. Rep. 2021, 11, 1-8. [CrossRef]

11. Kaewput, W.; Thongprayoon, C.; Rangsin, R.; Bathini, T.; Torres-Ortiz, A.; Mao, M.A.; Cheungpasitporn, W. Incidence and Risk Factors Associated with Outpatient Hypoglycemia in Patients with Type 2 Diabetes and Chronic Kidney Disease: A Nationwide Study. Endocr. Res. 2020, 45, 217-225. [CrossRef]

12. Chandran, S.R.; Jacob, P.; Choudhary, P. A systematic review of the effect of prior hypoglycaemia on cognitive function in type 1 diabetes. Ther. Adv. Endocrinol. Metab. 2020, 11, 2042018820906017. [CrossRef]

13. Whitmer, R.A.; Gilsanz, P.; Quesenberry, C.P.; Karter, A.J.; Lacy, M.E. Association of Type 1 Diabetes and Hypoglycemic and Hyperglycemic Events and Risk of Dementia. Neurology 2021, 97, e275-e283. [CrossRef] 
14. Jacobson, A.M.; Ryan, C.M.; Braffett, B.H.; Gubitosi-Klug, R.; Lorenzi, G.M.; Luchsinger, J.; Trapani, V.R.; Bebu, I.; Chaytor, N.; Hitt, S.M.; et al. Cognitive performance declines in older adults with type 1 diabetes: Results from 32 years of follow-up in the DCCT and EDIC Study. Lancet Diabetes Endocrinol. 2021, 9, 436-445. [CrossRef]

15. Barbagallo, M. Type 2 diabetes mellitus and Alzheimer's disease. World J. Diabetes 2014, 5, 889-893. [CrossRef]

16. Kim, Y.-G.; Park, D.G.; Moon, S.Y.; Jeon, J.Y.; Kim, H.J.; Kim, D.J.; Lee, K.-W.; Han, S.J. Hypoglycemia and Dementia Risk in Older Patients with Type 2 Diabetes Mellitus: A Propensity-Score Matched Analysis of a Population-Based Cohort Study. Diabetes Metab. J. 2020, 44, 125-133. [CrossRef]

17. Lauretti, E.; Li, J.-G.; Di Meco, A.; Praticò, D. Glucose deficit triggers tau pathology and synaptic dysfunction in a tauopathy mouse model. Transl. Psychiatry 2017, 7, e1020. [CrossRef]

18. Mavroeidi, P.; Mavrofrydi, O.; Pappa, E.; Panopoulou, M.; Papazafiri, P.; Haralambous, S.; Efthimiopoulos, S. Oxygen and Glucose Deprivation Alter Synaptic Distribution of Tau Protein: The Role of Phosphorylation. J. Alzheimer's Dis. 2017, 60, 593-604. [CrossRef]

19. Hanefeld, M.; Frier, B.M.; Pistrosch, F. Hypoglycemia and Cardiovascular Risk: Is There a Major Link? Diabetes Care 2016, 39 (Suppl. 2), S205-S209. [CrossRef]

20. Rehni, A.K.; Dave, K.R. Impact of Hypoglycemia on Brain Metabolism During Diabetes. Mol. Neurobiol. 2018, 55, 9075-9088. [CrossRef]

21. Rebholz-Schuhmann, D.; Oellrich, A.; Hoehndorf, R. Text-mining solutions for biomedical research: Enabling integrative biology. Nat. Rev. Genet. 2012, 13, 829-839. [CrossRef] [PubMed]

22. Demenkov, P.; Ivanisenko, T.; Kolchanov, N.; Ivanisenko, V. ANDVisio: A new tool for graphic visualization and analysis of literature mined associative gene networks in the ANDSystem. Silico Biol. 2012, 11, 149-161. [CrossRef] [PubMed]

23. Ivanisenko, V.A.; Saik, O.V.; Ivanisenko, N.V.; Tiys, E.S.; Ivanisenko, T.V.; Demenkov, P.S.; Kolchanov, N.A. ANDSystem: An Associative Network Discovery System for automated literature mining in the field of biology. BMC Syst. Biol. 2015, 9, S2. [CrossRef] [PubMed]

24. Ivanisenko, V.A.; Demenkov, P.S.; Ivanisenko, T.V.; Mishchenko, E.L.; Saik, O.V. A new version of the ANDSystem tool for automatic extraction of knowledge from scientific publications with expanded functionality for reconstruction of associative gene networks by considering tissue-specific gene expression. BMC Bioinform. 2019, 20 (Suppl. S5-S15), 34. [CrossRef]

25. Bragina, E.Y.; Tiys, E.; Freidin, M.B.; Koneva, L.A.; Demenkov, P.; Ivanisenko, V.; Kolchanov, N.; Puzyrev, V. Insights into pathophysiology of dystropy through the analysis of gene networks: An example of bronchial asthma and tuberculosis. Immunogenetics 2014, 66, 457-465. [CrossRef]

26. Saik, O.V.; Demenkov, P.S.; Ivanisenko, T.V.; Bragina, E.Y.; Freidin, M.B.; Goncharova, I.A.; Dosenko, V.E.; Zolotareva, O.I.; Hofestaedt, R.; Lavrik, I.N.; et al. Novel candidate genes important for asthma and hypertension comorbidity revealed from associative gene networks. BMC Med. Genom. 2018, 11 (Suppl. S1), 15. [CrossRef]

27. Saik, O.V.; Nimaev, V.V.; Usmonov, D.B.; Demenkov, P.S.; Ivanisenko, T.V.; Lavrik, I.N.; Ivanisenko, V.A. Prioritization of genes involved in endothelial cell apoptosis by their implication in lymphedema using an analysis of associative gene networks with ANDSystem. BMC Med. Genom. 2019, 12, 117-131. [CrossRef]

28. Saik, O.V.; Klimontov, V.V. Bioinformatic Reconstruction and Analysis of Gene Networks Related to Glucose Variability in Diabetes and Its Complications. Int. J. Mol. Sci. 2020, 21, 8691. [CrossRef]

29. Huang, D.W.; Sherman, B.T.; Lempicki, R. Systematic and integrative analysis of large gene lists using DAVID bioinformatics resources. Nat. Protoc. 2008, 4, 44-57. [CrossRef]

30. Bastian, F.B.; Roux, J.; Niknejad, A.; Comte, A.; Costa, S.S.F.; De Farias, T.M.; Moretti, S.; Parmentier, G.; De Laval, V.R.; Rosikiewicz, M.; et al. The Bgee suite: Integrated curated expression atlas and comparative transcriptomics in animals. Nucleic Acids Res. 2021, 49, D831-D847. [CrossRef]

31. Tesfaye, N.; Seaquist, E.R. Neuroendocrine responses to hypoglycemia. Ann. N. Y. Acad. Sci. 2010, 1212, 12-28. [CrossRef]

32. McNeilly, A.; McCrimmon, R.J. Impaired hypoglycaemia awareness in type 1 diabetes: Lessons from the lab. Diabetology 2018, 61, 743-750. [CrossRef]

33. Lin, X.; Qin, Y.; Jia, J.; Lin, T.; Lin, X.; Chen, L.; Zeng, H.; Han, Y.; Wu, L.; Huang, S.; et al. MiR-155 Enhances Insulin Sensitivity by Coordinated Regulation of Multiple Genes in Mice. PLoS Genet. 2016, 12, e1006308. [CrossRef]

34. Hennessy, E.; Clynes, M.; Jeppesen, P.B.; O'Driscoll, L. Identification of microRNAs with a role in glucose stimulated insulin secretion by expression profiling of MIN6 cells. Biochem. Biophys. Res. Commun. 2010, 396, 457-462. [CrossRef]

35. Meng, Q.; Yang, P.; Lu, Y. MicroRNA-410 serves as a candidate biomarker in hypoxic-ischemic encephalopathy newborns and provides neuroprotection in oxygen-glucose deprivation-injured PC12 and SH-SY5Y cells. Brain Behav. 2021, 11, 2293. [CrossRef]

36. Wang, J.; Carrillo, J.J.; Lin, H.V. GPR142 Agonists Stimulate Glucose-Dependent Insulin Secretion via Gq-Dependent Signaling. PLoS ONE 2016, 11, e0154452. [CrossRef]

37. Van Doorn, J.; Van De Hoef, W.; Dullaart, R.P.F. Quantitative analysis of the concentrations of IGFs and several IGF-binding proteins in a large fibrous abdominal tumor and the circulation of a patient with hypoglycemia. BioFactors 2015, 41, 183-189. [CrossRef]

38. Forsyth, L.; Scott, H.; Howatson, A.; Busuttil, A.; Hume, R.; Burchell, A. Genetic variation in hepatic glucose-6-phosphatase system genes in cases of sudden infant death syndrome. J. Pathol. 2007, 212, 112-120. [CrossRef] 
39. Soggia, A.P.; Correa-Giannella, M.L.; Fortes, M.A.H.; Luna, A.M.C.; Pereira, M.A.A. A novel mutation in the glycogen synthase 2 gene in a child with glycogen storage disease type 0. BMC Med. Genet. 2010, 11, 3. [CrossRef]

40. Liu, Q.; Lin, G.; Chen, Y.; Feng, W.; Xu, Y.; Lyu, J.; Yang, D.; Wang, M.-W. Deleterious mutation V369M in the mouse GCGR gene causes abnormal plasma amino acid levels indicative of a possible liver- $\alpha$-cell axis. Biosci. Rep. 2021, 41, 6. [CrossRef]

41. Jörneskog, G.; Lins, P.-E.; Adamson, U.; Fagrell, B. Patients with Type 1 Diabetes Lack Vasoconstrictor Response in Skin Microcirculation during Insulin-Induced Hypoglycemia. Int. J. Microcirc. 1994, 14, 262-268. [CrossRef]

42. Lei, H.; Preitner, F.; Labouèbe, G.; Gruetter, R.; Thorens, B. Glucose transporter 2 mediates the hypoglycemia-induced increase in cerebral blood flow. Br. J. Pharmacol. 2019, 39, 1725-1736. [CrossRef]

43. Trivedi, A.; Babic, S.; Heiman, M.; Chanoine, J.-P.; Gibson, W. Ghrelin, Ghrelin O-Acyltransferase, and Carbohydrate Metabolism During Pregnancy in Calorie-Restricted Mice. Horm. Metab. Res. 2016, 49, 64-72. [CrossRef]

44. Rask-Madsen, C.; King, G.L. Vascular Complications of Diabetes: Mechanisms of Injury and Protective Factors. Cell Metab. 2013, 17, 20-33. [CrossRef]

45. Ergul, A. Endothelin-1 and diabetic complications: Focus on the vasculature. Pharmacol. Res. 2011, 63, 477-482. [CrossRef]

46. Li, H.; Xu, H.; Li, Y.; Zhao, D.; Ma, B. Associations between erythropoietin polymorphisms and risk of diabetic microvascular complications. Oncotarget 2017, 8, 112675-112684. [CrossRef]

47. Bin Hong, S.; Lee, J.J.; Kim, S.H.; Suh, Y.J.; Han, J.Y.; Kim, Y.S.; Nam, M. The effects of adiponectin and inflammatory cytokines on diabetic vascular complications in obese and non-obese patients with type 2 diabetes mellitus. Diabetes Res. Clin. Pr. 2015, 111, 58-65. [CrossRef]

48. Peiró, C.; Lorenzo, O.; Carraro, R.; Sánchez-Ferrer, C.F. IL-1 $\beta$ Inhibition in Cardiovascular Complications Associated to Diabetes Mellitus. Front. Pharmacol. 2017, 8, 363. [CrossRef]

49. Qu, D.; Liu, J.; Lau, C.W.; Huang, Y. IL-6 in diabetes and cardiovascular complications. Br. J. Pharmacol. 2014, 171, 3595-3603. [CrossRef]

50. Van Nguyen, D.; Shaw, L.C.; Grant, M.B. Inflammation in the pathogenesis of microvascular complications in diabetes. Front. Endocrinol. 2012, 3, 170. [CrossRef]

51. Yamagishi, S.-I. Pleiotropic Effects of Glucagon-like Peptide-1 (GLP-1)-Based Therapies on Vascular Complications in Diabetes. Curr. Pharm. Des. 2011, 17, 4379-4385. [CrossRef] [PubMed]

52. Conti, E.; Pitocco, D.; Capoluongo, E.; Zuppi, C.; Ghirlanda, G.; Crea, F.; Andreotti, F. IGF-1 and macrovascular complications of diabetes: Alternative interpretations of recently published data. Diabetes Care 2003, 26, 1653-1654. [CrossRef] [PubMed]

53. Wirostko, B.; Wong, T.Y.; Simó, R. Vascular endothelial growth factor and diabetic complications. Prog. Retin. Eye Res. 2008, 27, 608-621. [CrossRef] [PubMed]

54. Aryan, Z.; Ghajar, A.; Faghihi-Kashani, S.; Afarideh, M.; Nakhjavani, M.; Esteghamati, A. Baseline High-Sensitivity C-Reactive Protein Predicts Macrovascular and Microvascular Complications of Type 2 Diabetes: A Population-Based Study. Ann. Nutr. Metab. 2018, 72, 287-295. [CrossRef]

55. Wang, J.; Xiao, M.; Wang, S.; Zhang, J.; Guo, Y.; Tang, Y.; Gu, J. NRF2-Related Epigenetic Modifications in Cardiac and Vascular Complications of Diabetes Mellitus. Front. Endocrinol. 2021, 12, 598005. [CrossRef]

56. Sun, W.-W.; Zhu, P.; Shi, Y.-C.; Zhang, C.-L.; Huang, X.-F.; Liang, S.-Y.; Song, Z.-Y.; Lin, S. Current views on neuropeptide Y and diabetes-related atherosclerosis. Diabetes Vasc. Dis. Res. 2017, 14, 277-284. [CrossRef]

57. Bondeva, T.; Wolf, G. Role of Neuropilin-1 in Diabetic Nephropathy. J. Clin. Med. 2015, 4, 1293-1311. [CrossRef]

58. Wang, J.; Wang, S.; Li, M.; Wu, D.; Liu, F.; Yang, R.; Ji, S.; Ji, A.; Li, Y. The Neuropilin-1 Inhibitor, ATWLPPR Peptide, Prevents Experimental Diabetes-Induced Retinal Injury by Preserving Vascular Integrity and Decreasing Oxidative Stress. PLoS ONE 2015, 10, e0142571. [CrossRef]

59. Sakurai, Y.; Inoue, H.; Shintani, N.; Arimori, A.; Hamagami, K.-I.; Hayata-Takano, A.; Baba, A.; Hashimoto, H. Compensatory Recovery of Blood Glucose Levels in KKAy Mice Fed a High-Fat Diet: Insulin-Sparing Effects of PACAP Overexpression in $\beta$ Cells. J. Mol. Neurosci. 2012, 48, 647-653. [CrossRef]

60. Dong, Q.L.; Zhao, X.H.; Wang, Q.; Zhang, L.P.; Yan, X.H.; Wang, X.M.; Li, Z.J.; Sun, Y. Anti-aging gene Klotho ameliorates diabetic nephropathy in mice by inhibiting FGF2 signaling pathway. J. Biol. Regul. Homeost. Agents 2020, 34, 1369-1377.

61. Wang, J.; Yao, Y.; Wang, K.; Li, J.; Chu, T.; Shen, H. MicroRNA-148a-3p alleviates high glucose-induced diabetic retinopathy by targeting TGFB2 and FGF2. Acta Diabetol. 2020, 57, 1435-1443. [CrossRef]

62. Li, R.; Ma, J.; Wu, Y.; Nangle, M.; Zou, S.; Li, Y.; Yin, J.; Zhao, Y.; Xu, H.; Zhang, H.; et al. Dual Delivery of NGF and bFGF Coacervater Ameliorates Diabetic Peripheral Neuropathy via Inhibiting Schwann Cells Apoptosis. Int. J. Biol. Sci. 2017, 13, 640-651. [CrossRef]

63. Liu, M.-H.; Tang, Z.-H.; Li, G.-H.; Qu, S.-L.; Zhang, Y.; Ren, Z.; Liu, L.-S.; Jiang, Z.-S. Janus-like role of fibroblast growth factor 2 in arteriosclerotic coronary artery disease: Atherogenesis and angiogenesis. J. Atheroscler. 2013, 229, 10-17. [CrossRef]

64. Rhee, S.Y. Hypoglycemia and Dementia. Endocrinol. Metab. 2017, 32, 195-199. [CrossRef]

65. Moin, A.S.M.; Kahal, H.; Al-Qaissi, A.; Kumar, N.; Sathyapalan, T.; Atkin, S.L.; Butler, A. Amyloid-related protein changes associated with dementia differ according to severity of hypoglycemia. BMJ Open Diabetes Res. Care 2021, 9, e002211. [CrossRef]

66. He, C.; Gao, P.; Cui, Y.; Li, Q.; Li, Y.; Lu, Z.; Ma, H.; Zhao, Y.; Li, L.; Sun, F.; et al. Low-glucose-sensitive TRPC6 dysfunction drives hypoglycemia-induced cognitive impairment in diabetes. Clin. Transl. Med. 2020, 10, 6-205. [CrossRef] 
67. Schouwenberg, B.J.; Veldman, B.A.; Spiering, W.; Coenen, M.J.; Franke, B.; Tack, C.J.; de Galan, B.E.; Smits, P. The Arg16Gly variant of the $\beta 2$-adrenergic receptor predisposes to hypoglycemia unawareness in type 1 diabetes mellitus. Pharm. Genom. 2008, 18, 369-372. [CrossRef]

68. Yu, J.-T.; Tan, L.; Ou, J.-R.; Zhu, J.-X.; Liu, K.; Song, J.-H.; Sun, Y.-P. Polymorphisms at the $\beta 2$-adrenergic receptor gene influence Alzheimer's disease susceptibility. Brain Res. 2008, 1210, 216-222. [CrossRef]

69. Niesporek, S.; Meyer, C.G.; Kremsner, P.G.; May, J. Polymorphisms of transporter associated with antigen processing type 1 (TAP1), proteasome subunit beta type 9 (PSMB9) and their common promoter in African children with different manifestations of malaria. Int. J. Immunogenet. 2005, 32, 7-11. [CrossRef]

70. Mishto, M.; Bellavista, E.; Santoro, A.; Stolzing, A.; Ligorio, C.; Nacmias, B.; Spazzafumo, L.; Chiappelli, M.; Licastro, F.; Sorbi, S.; et al. Immunoproteasome and LMP2 polymorphism in aged and Alzheimer's disease brains. Neurobiol. Aging 2006, 27, 54-66. [CrossRef]

71. Cuesta-Muñoz, A.L.; Huopio, H.; Otonkoski, T.; Gomez-Zumaquero, J.M.; Näntö-Salonen, K.; Rahier, J.; López-Enriquez, S.; García-Gimeno, M.A.; Sanz, P.; Soriguer, F.C.; et al. Severe Persistent Hyperinsulinemic Hypoglycemia due to a De Novo Glucokinase Mutation. Diabetes 2004, 53, 2164-2168. [CrossRef] [PubMed]

72. Solomon-Zemler, R.; Basel-Vanagaite, L.; Steier, D.; Yakar, S.; Mel, E.; Phillip, M.; Bazak, L.; Bercovich, D.; Werner, H.; De Vries, L. A novel heterozygous IGF-1 receptor mutation associated with hypoglycemia. Endocr. Connect. 2017, 6, 395-403. [CrossRef] [PubMed]

73. Yang, H.-C.; Liang, Y.-J.; Chen, J.-W.; Chiang, K.-M.; Chung, C.-M.; Ho, H.-Y.; Ting, C.-T.; Lin, T.-H.; Sheu, S.-H.; Tsai, W.-C.; et al. Identification of IGF1, SLC4A4, WWOX, and SFMBT1 as Hypertension Susceptibility Genes in Han Chinese with a Genome-Wide Gene-Based Association Study. PLoS ONE 2012, 7, e32907. [CrossRef] [PubMed]

74. Tatsi, C.; Xekouki, P.; Nioti, O.; Bachrach, B.; Belyavskaya, E.; Lyssikatos, C.; Stratakis, C.A. A novel mutation in the glucocorticoid receptor gene as a cause of severe glucocorticoid resistance complicated by hypertensive encephalopathy. J. Hypertens. 2019, 37, 1475-1481. [CrossRef]

75. Xiao, C.; Kim, H.-S.; Lahusen, T.; Wang, R.-H.; Xu, X.; Gavrilova, O.; Jou, W.; Gius, D.; Deng, C.-X. SIRT6 Deficiency Results in Severe Hypoglycemia by Enhancing Both Basal and Insulin-stimulated Glucose Uptake in Mice. J. Biol. Chem. 2010, 285, 36776-36784. [CrossRef]

76. Kuroda, Y.; Iwahashi, H.; Mineo, I.; Fukui, K.; Fukuhara, A.; Iwamoto, R.; Imagawa, A.; Shimomura, I. Hyperinsulinemic hypoglycemia syndrome associated with mutations in the human insulin receptor gene: Report of two cases. Endocr. J. 2015, 62, 353-362. [CrossRef]

77. Yan, X.; Hu, Y.; Wang, B.; Wang, S.; Zhang, X. Metabolic Dysregulation Contributes to the Progression of Alzheimer's Disease. Front. Neurosci. 2020, 14, 530219. [CrossRef]

78. Moll, L.; Schubert, M. The Role of Insulin and Insulin-Like Growth Factor-1/FoxO-Mediated Transcription for the Pathogenesis of Obesity-Associated Dementia. Curr. Gerontol. Geriatr. Res. 2012, 2012, 1-13. [CrossRef]

79. Chang, J.-Y.; Lee, M.-H.; Lin, S.-R.; Yang, L.-Y.; Sun, S.; Sze, C.-I.; Hong, Q.; Lin, Y.-S.; Chou, Y.-T.; Hsu, L.-J.; et al. Trafficking protein particle complex $6 \mathrm{~A}$ delta $(\mathrm{TRAPPC} 6 \mathrm{~A} \triangle \mathrm{)})$ is an extracellular plaque-forming protein in the brain. Oncotarget 2015, 6, 3578-3589. [CrossRef]

80. Escribano, L.; Simón, A.-M.; Pérez-Mediavilla, A.; Salazar-Colocho, P.; Del Río, J.; Frechilla, D. Rosiglitazone reverses memory decline and hippocampal glucocorticoid receptor down-regulation in an Alzheimer's disease mouse model. Biochem. Biophys. Res. Commun. 2009, 379, 406-410. [CrossRef]

81. Jung, E.S.; Choi, H.; Song, H.; Hwang, Y.J.; Kim, A.; Ryu, H.; Mook-Jung, I. p53-dependent SIRT6 expression protects A $\beta 42-$ induced DNA damage. Sci. Rep. 2016, 6, 25628. [CrossRef]

82. Schilbach, K.; Schubert, M. The Role of IGF-1 Receptor and Insulin Receptor Signaling for the Pathogenesis of Alzheimers Disease: From Model Organisms to Human Disease. Curr. Alzheimer Res. 2009, 6, 213-223. [CrossRef]

83. Ng, R.C.-L.; Chan, K.-H. Potential Neuroprotective Effects of Adiponectin in Alzheimer's Disease. Int. J. Mol. Sci. 2017, 18, 592. [CrossRef]

84. Silva, I.; Silva, J.; Ferreira, R.; Trigo, D. Glymphatic system, AQP4, and their implications in Alzheimer's disease. Neurol. Res. Pract. 2021, 3, 1-9. [CrossRef]

85. Westin, K.; Buchhave, P.; Nielsen, H.M.; Minthon, L.; Janciauskiene, S.; Hansson, O. CCL2 Is Associated with a Faster Rate of Cognitive Decline during Early Stages of Alzheimer's Disease. PLoS ONE 2012, 7, e30525. [CrossRef]

86. Tao, Q.; Ang, T.F.A.; Akhter-Khan, S.C.; Itchapurapu, I.S.; Killiany, R.; Zhang, X.; Budson, A.E.; Turk, K.W.; Goldstein, L.; Mez, J.; et al. Impact of C-Reactive Protein on Cognition and Alzheimer Disease Biomarkers in Homozygous APOE $\varepsilon 4$ Carriers. Neurology 2021, 97, e1243-e1252. [CrossRef]

87. Rozpedek, W.; Markiewicz, L.; Diehl, J.A.; Pytel, D.; Majsterek, I. Unfolded Protein Response and PERK Kinase as a New Therapeutic Target in the Pathogenesis of Alzheimer's Disease. Curr. Med. Chem. 2015, 22, 3169-3184. [CrossRef]

88. Sun, J.; Martin, J.M.; Vanderpoel, V.; Sumbria, R.K. The Promises and Challenges of Erythropoietin for Treatment of Alzheimer's Disease. NeuroMol. Med. 2019, 21, 12-24. [CrossRef]

89. Galle, S.A.; Van Der Spek, A.; Drent, M.L.; Brugts, M.P.; Scherder, E.J.A.; Janssen, J.A.; Ikram, M.A.; Van Duijn, C.M. Revisiting the Role of Insulin-Like Growth Factor-I Receptor Stimulating Activity and the Apolipoprotein E in Alzheimer's Disease. Front. Aging Neurosci. 2019, 11, 20. [CrossRef] 
90. Sohrabi, M.; Floden, A.M.; Manocha, G.D.; Klug, M.G.; Combs, C.K. IGF-1R Inhibitor Ameliorates Neuroinflammation in an Alzheimer's Disease Transgenic Mouse Model. Front. Cell. Neurosci. 2020, 14, 200. [CrossRef]

91. Carro, E.; Trejo, J.; Gerber, A.; Loetscher, H.; Torrado, J.; Metzger, F.; Torres-Aleman, I. Therapeutic actions of insulin-like growth factor I on APP/PS2 mice with severe brain amyloidosis. Neurobiol. Aging 2006, 27, 1250-1257. [CrossRef]

92. Mellott, T.J.; Pender, S.M.; Burke, R.M.; Langley, E.A.; Blusztajn, J.K. IGF2 Ameliorates Amyloidosis, Increases Cholinergic Marker Expression and Raises BMP9 and Neurotrophin Levels in the Hippocampus of the APPswePS1dE9 Alzheimer's Disease Model Mice. PLoS ONE 2014, 9, e94287. [CrossRef]

93. LeWitt, M.S.; Boyd, G.W. The Role of Insulin-Like Growth Factors and Insulin-Like Growth Factor-Binding Proteins in the Nervous System. Biochem. Insights 2019, 12, 1178626419842176. [CrossRef]

94. McGrath, E.R.; Himali, J.J.; Levy, D.; Conner, S.C.; DeCarli, C.S.; Pase, M.P.; Courchesne, P.; Satizabal, C.L.; Vasan, R.S.; Beiser, A.S.; et al. Circulating IGFBP-2: A novel biomarker for incident dementia. Ann. Clin. Transl. Neurol. 2019, 6, 1659-1670. [CrossRef]

95. Silva, N.M.L.; Gonçalves, R.A.; Pascoal, T.A.; Lima-Filho, R.A.S.; Resende, E.D.P.F.; Vieira, E.L.M.; Teixeira, A.L.; de Souza, L.C.; Peny, J.A.; Fortuna, J.T.S.; et al. Pro-inflammatory interleukin-6 signaling links cognitive impairments and peripheral metabolic alterations in Alzheimer's disease. Transl. Psychiatry 2021, 11, 1-15. [CrossRef]

96. Davinelli, S.; Sapere, N.; Zella, D.; Bracale, R.; Intrieri, M.; Scapagnini, G. Pleiotropic Protective Effects of Phytochemicals in Alzheimer's Disease. Oxid. Med. Cell. Longev. 2012, 2012, 1-11. [CrossRef]

97. Bahn, G.; Jo, D.-G. Therapeutic Approaches to Alzheimer's Disease Through Modulation of NRF2. NeuroMol. Med. 2019, $21,1-11$. [CrossRef]

98. Chabrier, P.-E.; Demerlé-Pallardy, C.; Auguet, M. Nitric oxide synthases: Targets for therapeutic strategies in neurological diseases. Cell. Mol. Life Sci. 1999, 55, 1029-1035. [CrossRef]

99. Duarte-Neves, J.; de Almeida, L.P.; Cavadas, C. Neuropeptide Y (NPY) as a therapeutic target for neurodegenerative diseases. Neurobiol. Dis. 2016, 95, 210-224. [CrossRef]

100. Li, C.; Wu, X.; Liu, S.; Zhao, Y.; Zhu, J.; Liu, K. Roles of Neuropeptide Y in Neurodegenerative and Neuroimmune Diseases. Front. Neurosci. 2019, 13, 869. [CrossRef]

101. Hijioka, M.; Inden, M.; Yanagisawa, D.; Kitamura, Y. DJ-1/PARK7: A New Therapeutic Target for Neurodegenerative Disorders. Biol. Pharm. Bull. 2017, 40, 548-552. [CrossRef] [PubMed]

102. Kutz, S.M.; Higgins, C.E.; Higgins, P.J. Novel Combinatorial Therapeutic Targeting of PAI-1(SERPINE1) Gene Expression in Alzheimer's Disease. Mol. Med. Ther. 2012, 1, 106. [CrossRef]

103. Wong, S.Y.; Tang, B.L. SIRT1 as a therapeutic target for Alzheimer's disease. Rev. Neurosci. 2016, 27, 813-825. [CrossRef] [PubMed]

104. Akter, R.; Afrose, A.; Rahman, R.; Chowdhury, R.; Nirzhor, S.; Khan, R.; Kabir, T. A Comprehensive Analysis into the Therapeutic Application of Natural Products as SIRT6 Modulators in Alzheimer's Disease, Aging, Cancer, Inflammation, and Diabetes. Int. J. Mol. Sci. 2021, 22, 4180. [CrossRef] [PubMed]

105. Kwok, M.K.; Lin, S.L.; Schooling, C.M. Re-thinking Alzheimer's disease therapeutic targets using gene-based tests. EBioMedicine 2018, 37, 461-470. [CrossRef]

106. Hu, C.; Tao, L.; Cao, X.; Chen, L. The solute carrier transporters and the brain: Physiological and pharmacological implications. Asian J. Pharm. Sci. 2019, 15, 131-144. [CrossRef]

107. Cheng, X.; Shen, Y.; Li, R. Targeting TNF: A therapeutic strategy for Alzheimer's disease. Drug Discov. Today 2014, 19, 1822-1827. [CrossRef]

108. Zhou, M.; Xu, R.; Kaelber, D.; Gurney, M.E. Tumor Necrosis Factor (TNF) blocking agents are associated with lower risk for Alzheimer's disease in patients with rheumatoid arthritis and psoriasis. PLoS ONE 2020, 15, e0229819. [CrossRef]

109. Cho, S.-J.; Park, M.H.; Han, C.; Yoon, K.; Koh, Y.H. VEGFR2 alteration in Alzheimer's disease. Sci. Rep. 2017, 7, 1-11. [CrossRef]

110. Ryan, C.M.; Klein, B.E.; Lee, K.E.; Cruickshanks, K.J.; Klein, R. Associations between recent severe hypoglycemia, retinal vessel diameters, and cognition in adults with type 1 diabetes. J. Diabetes Complicat. 2016, 30, 1513-1518. [CrossRef]

111. Virtanen, P.; Gommers, R.; Oliphant, T.E.; Haberland, M.; Reddy, T.; Cournapeau, D.; Burovski, E.; Peterson, P.; Weckesser, W.; Bright, J.; et al. SciPy 1.0: Fundamental algorithms for scientific computing in Python. Nat. Methods 2020, 17, 261-272. [CrossRef]

112. Carbon, S.; Ireland, A.; Mungall, C.; Shu, S.; Marshall, B.; Lewis, S.; AmiGO Hub; Web Presence Working Group. AmiGO: Online access to ontology and annotation data. Bioinformatics 2008, 25, 288-289. [CrossRef] 